\title{
Mineralogical characterization of clay mineral assemblages from Rio de Janeiro pegmatites to identify kaolinite and/or halloysite deposits
}

\section{(Caracterização mineralógica das associações de argilominerais em pegmatitos do estado do Rio de Janeiro com enfoque na identificação de depósitos de caulinita e/ou halloysita)}

\author{
V. M. J.Salgado-Campos ${ }^{1,2 *}$, L.C.Bertolino ${ }^{2,3}$, F. J. da Silva ${ }^{4}$, J. C.Mendes ${ }^{1}$ \\ ${ }^{I}$ Federal University of Rio de Janeiro, Institute of Geosciences, Graduate Program in Geology, Av. Athos da \\ Silveira Ramos 274, 21941-909, Rio de Janeiro, RJ, Brazil \\ ${ }^{2}$ Center for Mineral Technology, Division for Mineral Analyses, Sector for Mineral Technology, \\ Rio de Janeiro. RJ, Brazil \\ ${ }^{3}$ State University of Rio de Janeiro, Faculty of Geology, Department of Mineralogy and Igneous Petrology, \\ Rio de Janeiro, RJ, Brazil \\ ${ }^{4}$ Federal Rural University of Rio de Janeiro, Institute of Agronomy, Department of Petrology and Geotectonic, \\ Seropédica, RJ, Brazil
}

\begin{abstract}
This study reports the mineralogical characterization of kaolin occurrences in the State of Rio de Janeiro, Brazil, to identify new kaolinite and halloysite deposits. Samples were collected in 10 pegmatites with varying sizes for X-ray diffractometry, chemical analysis by X-ray fluorescence, and scanning electron microscopy studies. The results indicated that the kaolin occurrences were of weathered origin, wherein some places there were occurrences of tubular halloysite. Concerning the regolith stratigraphy, samples located in the saprock zone were found to contain kaolinite and/or halloysite contents from 0 to $10.1 \%$, while those located in the saprolite zone contained kaolinite and/or halloysite contents from $16.3 \%$ to $34.9 \%$. Kaolinite and/or halloysite-7 $\mathrm{A}$ were formed from plagioclase weathering instead of K-feldspar or mica, and the halloysite-7 $\AA$ occurrence was related to samples in regions with a higher degree of weathering.
\end{abstract}

Keywords: kaolin, kaolinite, halloysite, Rietveld, Rio de Janeiro.

Resumo

Este estudo reporta a caracterização mineralógica de ocorrências de caulim no estado do Rio de Janeiro, Brasil, com enfoque na identificação de depósitos de caulinita elou halloysita. Amostras foram coletadas em 10 pegmatitos de dimensões variadas para estudos de difratometria de raios $X$, análise química por fluorescência de raios X e microscopia eletrônica de varredura. As ocorrências de caulim nos corpos pegmatíticos foram de origem intempérica, onde em alguns locais houve ocorrência de halloysita tubular. Dentro da estratigrafia do regolito, as amostras localizadas na zona de saprock apresentaram teores de caulinita elou halloysita entre 0 e 10,1\%, enquanto aquelas localizadas no saprólito apresentaram maiores teores de caulinita entre 16,3\% e 34,9\%. A caulinita elou halloysita foram formadas a partir da alteração de plagioclásio e não de K-feldspato ou mica, estando a ocorrência de halloysita associada a locais de grau de intemperismo mais elevado.

Palavras-chave: caulim, caulinita, halloysita, Rietveld, Rio de Janeiro.

\section{INTRODUCTION}

Kaolin is a fine-grained white rock/ore composed mostly of kaolinite, halloysite, or other kaolinite polytypes [1]. The material is used in many industrial segments, mainly in the ceramic and paper industries [2]. Moreover, halloysite kaolin deposits have been studied since 2005 [3] for nobler

*victorsalgadocampos@hotmail.com

(Dhttps://orcid.org/0000-0001-7662-1186 applications in nanotechnology because the substance is considered to be a more environmentally friendly nanotube source [4]. It is used in pharmaceuticals as an active principle carrier [5], in polymers as filler [6], as well as to make anticorrosive paint [7], among others. Kaolin deposits can be classified as primary when arising from in situ silicate alteration, typically of feldspar, or as secondary, when having sedimentary origin [8]. There are primary kaolin deposits hosted in pegmatites, which are generally granitic rocks with coarser grain size than the host rock [9], and that can be zoned or not [10]. These lithologies are found in pegmatite 
provinces, which are large areas containing a considerable number of pegmatite bodies. This type of deposit can have a hydrothermal or weathering origin, in the last case where the quality is associated with the pegmatite weathering degree. Concerning regolith stratigraphy, kaolin deposits generally occur in the saprolite zone, which has a higher weathering degree, while deposits in the saprock zone, which are located between the crude rock and saprolite zones, have lesser kaolinite and/or halloysite contents. Saprock forms the zone where less than $20 \%$ of weatherable minerals are weathered, while saprolite is in the zone where more than $20 \%$ of the weatherable minerals are weathered [11].

Besides Brazil, kaolinitic kaolin deposits are found in the Hagendorf-Pleystein Pegmatite Province (Germany) [12] and the Spruce Pine deposit (USA) [13], while kaolinite and halloysite mixtures are found in the Bombowha deposit (Ethiopia) [14, 15] and the Swat deposits (Pakistan) [16]. Brazil is the world's $7^{\text {th }}$-leading kaolin producer, with 1.7 Mtpa [17], and its deposits are found mainly in the Capim River [18] and Jari River [19] sedimentary deposits in the North region, and in the primary deposits of the Borborema Pegmatite Province [20-22] and Oriental Pegmatite Province $[23,24]$. In the Brazilian Southeast and South regions, kaolin deposits from the Oriental Pegmatite Province are found in the State of Minas Gerais, primary deposits hosted in granites in São Paulo [25], primary deposits hosted in acid volcanic rocks in Paraná [26] and Santa Catarina [27], and primary deposits hosted in anorthosites in the Rio Grande do Sul [25]. There is also a small kaolin occurrence in Espírito Santo [28]. In Rio de Janeiro State, nowadays, there are kaolin occurrences in the municipalities of Magé [24], Valença [24], Sapucaia [29], Petrópolis [29], Itatiaia [30], Araruama [30], and Rio de Janeiro [31], while other kaolin deposits in the State's northern region were depleted between 1940 and 1980 [32]. Data concerning kaolin production in Rio de Janeiro is quite inaccurate, as well as data about the volume and estimated reserves. Generally, the kaolin production in Rio de Janeiro is made by small companies, which do not have conditions to size ore reserves with precision. Studies to identify prospective new occurrences in the Rio de Janeiro, as well as its mineralogical description is necessary to understand the mining potential of the State, where dozens of pegmatite bodies are cataloged [33] but have not been studied to detect kaolin. Therefore, here we report the mineralogical, chemical, micromorphological, and genetic characterization of kaolin occurrences in Rio de Janeiro to identify new commercial deposits.

\section{MATERIALS AND METHODS}

Sampling sites: the overall study area was the Rio de Janeiro Pegmatite Province, Brazil, which was subdivided into 5 areas: Niterói-Rio Bonito; Cantagalo-São Fidélis; Paraíba do Sul; Casemiro de Abreu-Glicério; and Barra Mansa-Barra do Piraí (Fig. 1) [32]. The first two were visited for the prospection of pegmatite bodies, in which the catalog of pegmatites from Rio de Janeiro [33] was used as a guide to investigating the pegmatites described as having kaolin occurrences. The Cantagalo-São Fidelis area, containing the municipality of Cantagalo, covers $3300 \mathrm{~km}^{2}$ and has the occurrence of pegmatites named Córrego do Ouro (CA-3), Esmério (CA-4), and Boa Sorte Superior (CA2), the first two with kaolin occurrences. The Niterói-Rio Bonito area, covering the municipalities of Rio Bonito, São Gonçalo, and Maricá, has $1700 \mathrm{~km}^{2}$ and contains the pegmatite bodies designated RB-1, RB-2, RB-3, RB-4, RB-5, RB-6, RB-7, SG-1, SG-2, SG-3, SG-4, and Calaboca-Rebentão, in which bodies SG2, SG-3, SG-4, and Calaboca-Rebentão did not present kaolin occurrences. In Cantagalo, the Córrego do Ouro pegmatite body has a length of $25 \mathrm{~m}$ and a height of nearly $15 \mathrm{~m}$, from which feldspar was extracted in the 1980s (Fig. 2A). The Esmério pegmatite body, probably the biggest in Rio de Janeiro, has a length of $200 \mathrm{~m}$, the height of $50 \mathrm{~m}$, with lenticular geometry, and was utilized to mine feldspar and rubellite during the 1960s, where kaolin occurrences were also identified (Figs. 2B and $2 \mathrm{C})$. The Boa Sorte Superior pegmatite body was exploited for mica and kaolin during the 1940s, by open-pit mining, which was reactivated in 1970 to extract feldspar. The pegmatite body there is $30 \mathrm{~m}$ high and $8 \mathrm{~m}$ wide, with no occurrence of kaolin [33]. In Rio Bonito, the RB-1 pegmatite occurs on a road cut and has large dimensions (Fig. 2D). The RB-2 pegmatite apparently was already exploited and is nearly $10 \mathrm{~m}$ long and $8 \mathrm{~m}$ wide (Fig. 2E). The RB-3 pegmatite is $5 \mathrm{~m}$ in length, width, and height and is reddish (Fig. 2F). The RB-4 pegmatite deposit has many small pegmatite bodies with a centimeter thickness (Figs. $2 \mathrm{G}$ and $2 \mathrm{H}$ ) with kaolin occurrence. The RB-5 pegmatite is 10 $\mathrm{m}$ high, $4 \mathrm{~m}$ long, and $2 \mathrm{~m}$ wide (Fig. 2I). The RB-6 pegmatite is $10 \mathrm{~m}$ long and $10 \mathrm{~m}$ high, where there is white-colored kaolin occurrence (Fig. 2J). The RB-7 pegmatite can be associated with alkaline rocks and has small dimensions (Fig. 2K). In São Gonçalo, the SG-1 pegmatite deposit is located in a quarry, with an approximate thickness of $3 \mathrm{~m}$ and is discordant, wherein the uppermost portion contains kaolin (Fig. 2L). The SG-2, SG-3, and SG-4 bodies do not present kaolin occurrences, nor does the Calaboca-Rebentão pegmatite (MA-1).

16 samples from the 10 pegmatite bodies previously described were collected (Table I). The samples were dried at $60{ }^{\circ} \mathrm{C}$ for $24 \mathrm{~h}$, submitted to jaw crushing to produce $<2 \mathrm{~mm}$ grain size and divided into aliquots of $1 \mathrm{~kg}$. Then, smaller aliquots were submitted to vibratory ring milling for $30 \mathrm{~s}$ at $700 \mathrm{rpm}$ to obtain fractions less than $106 \mu \mathrm{m}$ with precautions to avoid sample amorphization. After that, the fractions were processed in a McCrone mill to generate fractions less than $10 \mu \mathrm{m}$ for quantitative mineral analysis. Other aliquots of $1 \mathrm{~kg}$ were submitted to granulometric classification in wet conditions in vibratory sieves of $20 \mu \mathrm{m}$ before the separation of the clay fraction using Stokes' law, employing an ultrasonic bath and sodium hexametaphosphate $(3 \mathrm{mg} / \mathrm{g}$ ) as dispersant agent. After that, bulk samples were analyzed by X-ray diffractometry (XRD) for quantitative mineral analysis and X-ray fluorescence spectroscopy (XRF) for chemical analysis. Clay size fractions were studied through XRD and scanning electron microscopy (SEM). $\mathrm{X}$-ray diffractograms for quantitative mineral analysis were acquired in a Bruker D4 Endeavor diffractometer with 

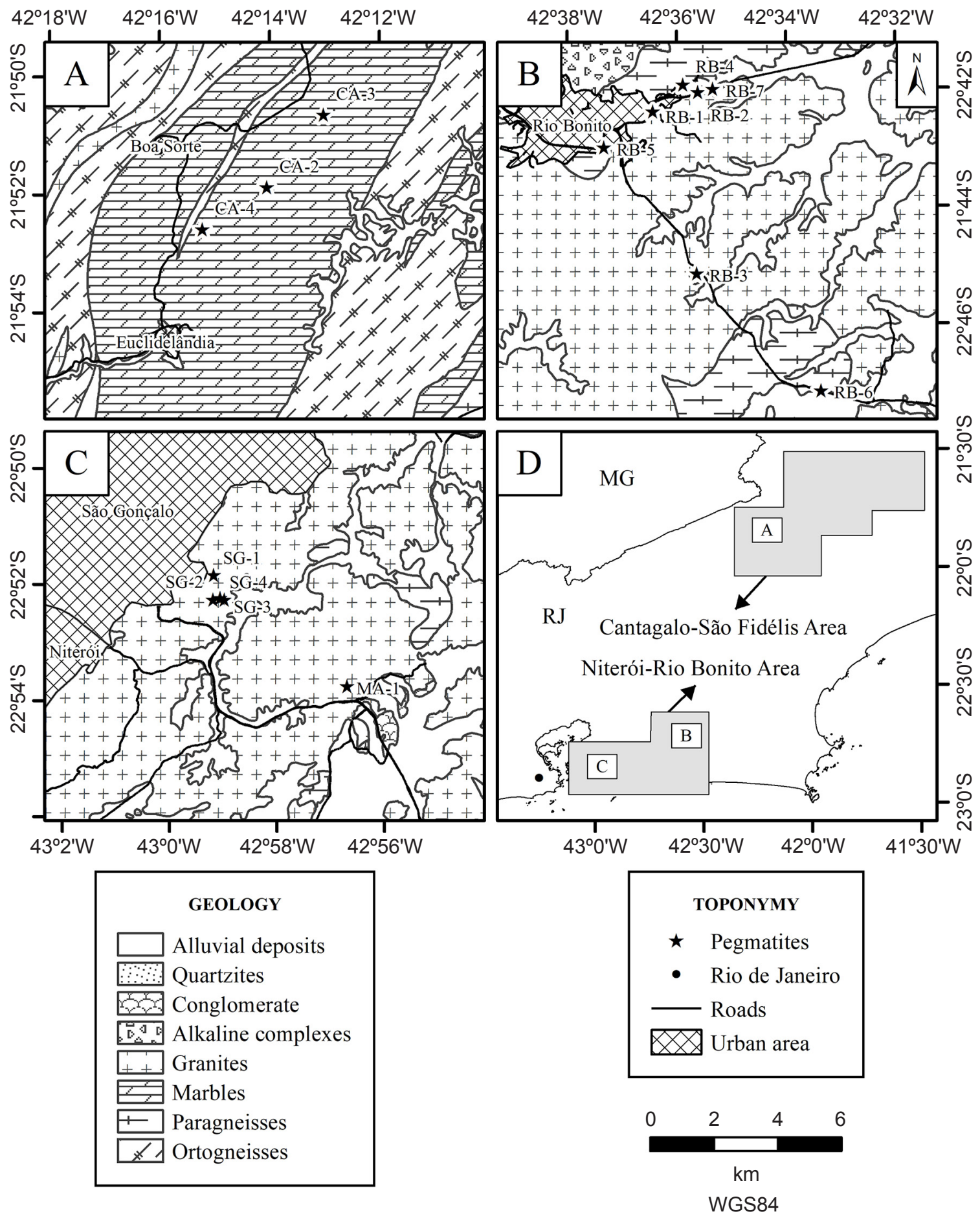

Figure 1: Geological map with sampling locations in the Rio de Janeiro Pegmatite Province (RJPP), in which the scale bar is associated with maps A, B, and C [32, 34]: A) Cantagalo-São Fidélis area; B) site near Rio Bonito in the Niterói-Rio Bonito area; C) site near São Gonçalo in the Niteroi-Rio Bonito area; and D) map of the central portion of Rio de Janeiro State, highlighting the Cantagalo-São Fidélis and NiteróiRio Bonito areas in the geological context of the RJPP, containing the locations of maps A, B, and C.

[Figura 1: Mapa geológico com localizações de coleta das amostras na Província Pegmatítica do Rio de Janeiro (PPRJ), onde a escala está associada aos mapas A, B e C [32, 34]: A) área Cantagalo-São Fidélis; B) área próxima a Rio Bonito na área Niterói-Rio Bonito; C) área próxima a São Gonçalo na área Niterói-Rio Bonito; e D) mapa da porção central do estado do Rio de Janeiro com destaque para as áreas Cantagalo-São Fidélis e Niterói-Rio Bonito no contexto geológico da PPRJ, onde estão assinaladas as localidades dos mapas A, B e C.]

$\operatorname{CoK} \alpha(\lambda=1.79021 \AA)$ radiation, operated at $40 \mathrm{kV}$ and 40 $\mathrm{mA}$ with goniometer velocity of $0.01^{\circ}(2 \theta)$ per $1 \mathrm{~s}$ in the range between $4^{\circ}$ and $105^{\circ}(2 \theta)$. The quantitative mineral analysis was performed with software (TOPAS v.5, Bruker), and structures available in the ICDD database (2019) were used in the refinement [35]. Sample positions in regolith 

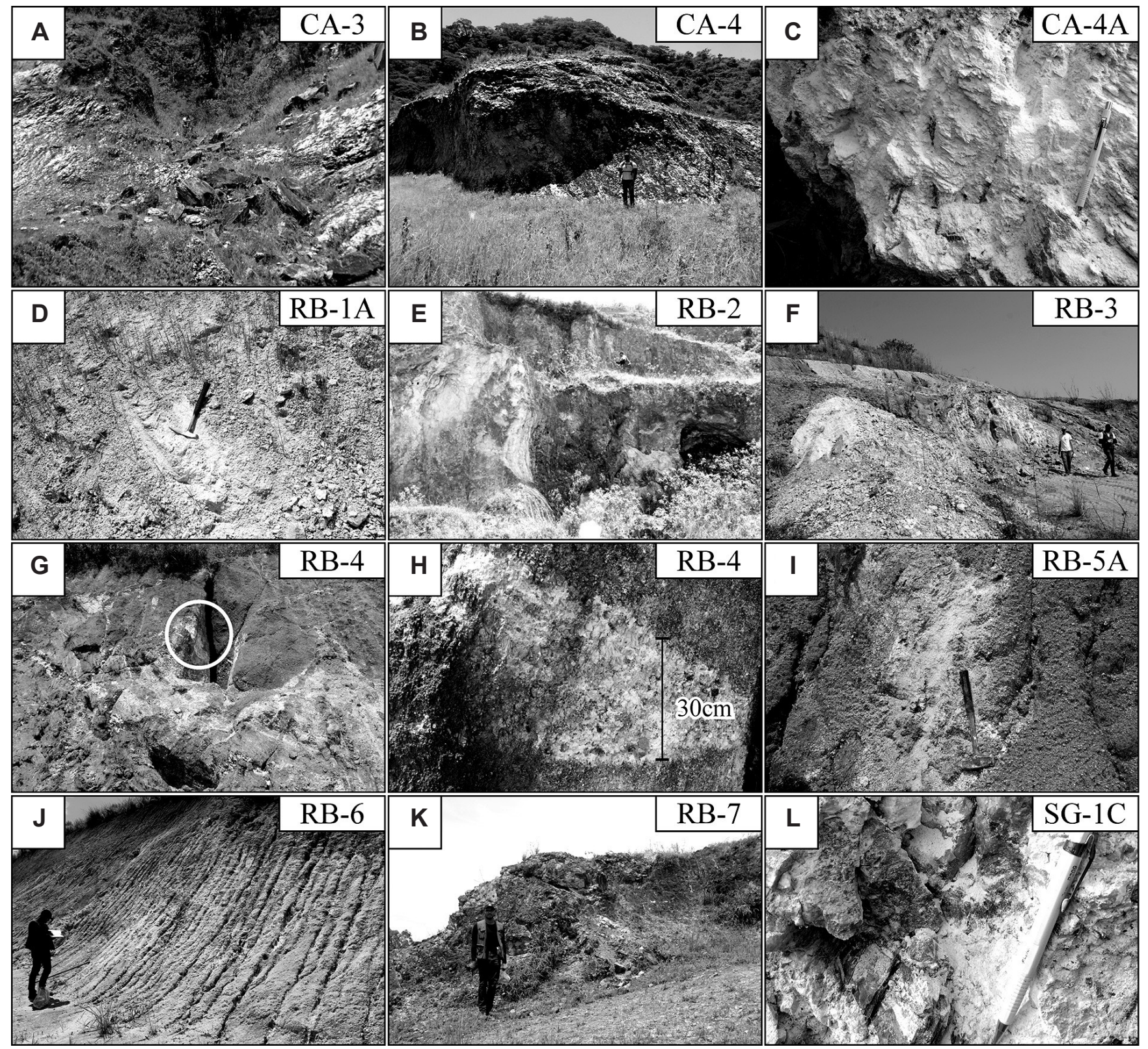

Figure 2: Pegmatite body images: A) Córrego do Ouro (CA-3) front view; B) feldspar mining front view from the 1960s in the Esmério pegmatite (CA-4); C) sampling location of kaolin (CA-4A) in the Esmério pegmatite; D) RB-1 pegmatite; E) front view of RB-2 pegmatite; F) side view of body RB-3; G) overview of the pegmatite swarm in RB-4; H) detailed view (circle in 2G), in which the sampling took place; I) sampling location of RB-5A; J) side view of RB-6 pegmatite; K) body RB-7; and L) sampling location in SG-1 pegmatite.

[Figura 2: Imagens dos pegmatitos: A) visão frontal do pegmatito Córrego do Ouro (CA-3); B) frente de lavra de feldspato da década de 1960 no pegmatito Esmério (CA-4); C) local de amostragem de caulim (CA-4A) no pegmatito Esmério; D) pegmatito RB-1; E) vista frontal do pegmatito $R B-2 ; F)$ visão lateral do corpo $R B-3 ; G)$ visão afastada do enxame de pegmatitos no ponto RB-4; $H)$ região em detalhe (círculo em $2 G$ ), onde foi realizada a amostragem; I) local de coleta da amostra RB-5A; J) visão lateral do pegmatito RB-6; K) corpo RB-7; e L) local de amostragem no pegmatito SG-1.]

stratigraphy (RE) were verified through Eq. A, in which $\mathrm{K} \ln +\mathrm{Hly}$ is the sum of the kaolinite and halloysite contents, $\mathrm{Sm}$ is the smectite content, Kfs is the K-feldspar content, $\mathrm{Pl}$ is the plagioclase content, and $\mathrm{Mi}+\mathrm{Ill}$ is the sum of mica and illite contents (since the differentiation of mica and illite is not possible through XRD). When the result is $\leq 20 \%$, the sample is from the saprock zone, while when the result is $>20 \%$, the sample is from the saprolite zone [11].

$$
\mathrm{RE}=\frac{(\mathrm{Kln}+\mathrm{Hly})+\mathrm{Sm}}{\mathrm{Kfs}+\mathrm{pl}+(\mathrm{Mi}+\mathrm{Ill})+(\mathrm{Kln}+\mathrm{Hly})+\mathrm{Sm}} \cdot 100
$$

Clay size fractions were analyzed through the orientedslide method [36], in which samples on glass slides were air-dried, treated with ethylene-glycol for $16 \mathrm{~h}$, and heated at $550{ }^{\circ} \mathrm{C}$ for $2 \mathrm{~h}$. Then, X-ray diffractograms were acquired in the same diffractometer but using a goniometer velocity 
Table I - Sampling sites in the Cantagalo-São Fidélis and Niterói-Rio Bonito areas.

[Tabela I - Locais de amostragem nas áreas Cantagalo-São Fidélis e Niterói-Rio Bonito.]

\begin{tabular}{|c|c|c|c|c|c|c|}
\hline Pegmatite & $\begin{array}{c}\text { Number of } \\
\text { samples }\end{array}$ & Area & Municipality & Latitude & Longitude & $\begin{array}{c}\text { Elevation } \\
(\mathrm{m})\end{array}$ \\
\hline Córrego do Ouro (CA-3) & 2 & $\begin{array}{l}\text { Cantagalo-São } \\
\text { Fidélis }\end{array}$ & Cantagalo & -21.842 & -42.217 & 332 \\
\hline Boa Sorte Superior (CA-2) & $0 *$ & $\begin{array}{l}\text { Cantagalo-São } \\
\text { Fidélis }\end{array}$ & Cantagalo & -21.863 & -42.233 & 370 \\
\hline Esmério (CA-4) & 2 & $\begin{array}{l}\text { Cantagalo-São } \\
\text { Fidélis }\end{array}$ & Cantagalo & -21.875 & -42.251 & 426 \\
\hline RB-1 & 2 & Niterói-Rio Bonito & Rio Bonito & -22.708 & -42.607 & 74 \\
\hline RB-2 & 2 & Niterói-Rio Bonito & Rio Bonito & -22.703 & -42.593 & 71 \\
\hline RB-3 & 2 & Niterói-Rio Bonito & Rio Bonito & -22.754 & -42.593 & 97 \\
\hline RB-4 & 1 & Niterói-Rio Bonito & Rio Bonito & -22.700 & -42.598 & 74 \\
\hline RB-5 & 2 & Niterói-Rio Bonito & Rio Bonito & -22.719 & -42.622 & 75 \\
\hline RB-6 & 1 & Niterói-Rio Bonito & Rio Bonito & -22.786 & -42.554 & 71 \\
\hline RB-7 & 1 & Niterói-Rio Bonito & Rio Bonito & -22.702 & -42.589 & 59 \\
\hline $\begin{array}{l}\text { Calaboca-Rebentão (MA- } \\
\text { 1) }\end{array}$ & $0 *$ & Niterói-Rio Bonito & Maricá & -22.895 & -42.946 & 41 \\
\hline SG-1 & 1 & Niterói-Rio Bonito & São Gonçalo & -22.863 & -42.987 & 63 \\
\hline SG-2 & $0 *$ & Niterói-Rio Bonito & São Gonçalo & -22.863 & -42.987 & 76 \\
\hline SG-3 & $0 *$ & Niterói-Rio Bonito & São Gonçalo & -22.870 & -42.987 & 96 \\
\hline SG-4 & $0^{*}$ & Niterói-Rio Bonito & São Gonçalo & -22.870 & -42.984 & 85 \\
\hline
\end{tabular}

* no occurrence of kaolin.

of $0.01^{\circ}(2 \theta)$ per $0.5 \mathrm{~s}$ in the range between $2^{\circ}$ and $40^{\circ}(2 \theta)$. The diffractograms used for distinguishing clay minerals species using $\mathrm{d}(060)$ reflections [37] were obtained with random mounted samples in the interval between 1.84 and $1.46 \AA$ in a diffractometer (D8 Advance, Bruker) with $\mathrm{CuK} \alpha$ $(\lambda=1.5406 \AA)$ radiation in the conditions of $40 \mathrm{kV}$ and $25 \mathrm{~mA}$, goniometer velocity of $0.02^{\circ}(2 \theta)$ per step with a counting time of $0.5 \mathrm{~s}$ per step. The quantification of clay minerals was made following the Biscaye's method [38], in which the area of the main basal reflection of each clay mineral $\left(\mathrm{d}_{001}\right)$ in the diffractograms obtained from the ethylene-glycol solvated glass slides was measured in relation to the sum of all peak areas, being weights attributed to them in order to correct the effect of full width at half-maximum of each clay mineral. The method states that smectite, illite, and kaolinite receive weights 1,4 , and 2 , respectively, and, in the present study, rectorite received weight 1 .

Chemical analysis was carried out by X-ray fluorescence spectroscopy (XRF) in a spectrometer (Axios mAX, PANalytical) in which the fractions were prepared in an automatic press (Vaneox) with $20 \mathrm{~mm}$ diameter with a pressure of 20 ton for $30 \mathrm{~s}$, utilizing boric acid $\left(\mathrm{H}_{3} \mathrm{BO}_{3}\right.$, Merck, R.G.) in the proportion of 1:0.1. The loss on ignition (LOI) was quantified in duplicate through the difference between the sample mass before and after heating at 1000 ${ }^{\circ} \mathrm{C}$ for $16 \mathrm{~h}$. The quantitative mineral analysis values were converted into chemical analysis values and compared to the
XRF results, considering the chemical compositions of the minerals from an open-source website (www.webmineral. com), except kaolinite and halloysite which oxide contents were based on unpublished data (Table II). The chemical analysis was also used to obtain the chemical index of alteration (CIA) [39] through Eq. B, in which the oxides' molar proportions were used, considering only $\mathrm{CaO}$ content

Table II - Chemical compositions (wt \%) used in the conversion of results from quantitative mineral analysis to chemical analysis.

[Tabela II - Composições químicas (\% em massa) usadas na conversão dos resultados de análise mineral quantitativa em análise química.]

\begin{tabular}{ccccccc}
\hline Content & Mo & Ms & Kln/Hly & Qtz & Kfs & Pl \\
\hline $\mathrm{SiO}_{2}$ & 43.77 & 45.21 & 43.22 & 100.00 & 64.76 & 67.39 \\
$\mathrm{Al}_{2} \mathrm{O}_{3}$ & 18.57 & 38.36 & 42.82 & 0.00 & 18.32 & 20.35 \\
$\mathrm{CaO}$ & 1.02 & 0.00 & 0.00 & 0.00 & 0.00 & 1.07 \\
$\mathrm{Na}_{2} \mathrm{O}$ & 1.13 & 0.00 & 0.00 & 0.00 & 0.00 & 11.19 \\
$\mathrm{~K}_{2} \mathrm{O}$ & 0.00 & 11.81 & 0.00 & 0.00 & 16.92 & 0.00 \\
$\mathrm{LOI}$ & 36.09 & 4.07 & 13.96 & 0.00 & 0.00 & 0.00 \\
$\mathrm{~F}$ & 0.00 & 0.55 & 0.00 & 0.00 & 0.00 & 0.00 \\
$\mathrm{Sum}$ & 100.58 & 100.00 & 100.00 & 100.00 & 100.00 & 100.00 \\
\hline
\end{tabular}

Mo: montmorillonite; Ms: muscovite; Kln/Hly: kaolinite and/or halloysite; Qtz: quartz; Kfs: K-feldspar; Pl: plagioclase. 
from silicate origin. The index was used to determine the weathering degree that rock was submitted.

$$
\mathrm{CIA}=\frac{\mathrm{Al}_{2} \mathrm{O}_{3}}{\mathrm{Al}_{2} \mathrm{O}_{3}+\mathrm{CaO}+\mathrm{Na}_{2} \mathrm{O}+\mathrm{K}_{2} \mathrm{O}} \cdot 100
$$

Pearson correlation coefficients (Q), used to construct matrices, were calculated with the OriginPro2020 software, and the values obtained were classified following the convention in Table III. The scanning electron microscopy (SEM) images were acquired in a microscope (TM3030Plus, Hitachi) operating at $15 \mathrm{kV}$ in a low vacuum mode. The samples were sputter-coated with silver in a sputter coater (SCD 005, Bal-Tec) for $250 \mathrm{~s}$ at $30 \mathrm{~mA}$.

Table III - Classification by Pearson correlation coefficients. [Tabela III - Convenção utilizada para avaliação dos coeficientes de correlação de Pearson.]

\begin{tabular}{cc}
\hline Q value $(+$ or -$)$ & Interpretation \\
\hline 0.00 to 0.19 & Very weak correlation \\
0.20 to 0.39 & Weak correlation \\
0.40 to 0.69 & Moderate correlation \\
0.70 to 0.89 & Strong correlation \\
0.90 to 1.00 & Very strong correlation \\
\hline
\end{tabular}

\section{RESULTS}

Quantitative mineral analysis (XRD) and chemical analysis $(X R F)$ : smectite was identified in samples CA$3 \mathrm{~B}, \mathrm{RB}-3 \mathrm{~B}$, and RB-5A by basal reflection at $15 \AA$ (001), mica and/or illite were identified in all the samples by basal reflections at $9.98 \AA$ (001) and $4.98 \AA$ (002), kaolinite and/ or halloysite in all the samples except CA-3 and RB-3B by basal reflection at $7 \AA$ (001), quartz in all the samples by reflections at $4.25 \AA$, $\mathrm{K}$-feldspar in all of the samples except RB-2, RB-3B, and RB-7 by reflections at 6.34 and $3.24 \AA$, and plagioclase in samples CA-3, CA-4, RB-1, RB-3A, and SG-1C by reflection at $3.18 \AA$ (Fig. 3). In the Cantagalo area, kaolinite did not occur in the Córrego do Ouro pegmatite (CA-3), while two samples from Esmério pegmatite had contents close to $4 \%$ (Table IV). In Rio Bonito, RB-1 pegmatite showed kaolinite contents between $1.6 \%$ (RB-1B) and $6.4 \%$ (RB-1A), and RB-2 pegmatite presented kaolinite contents between $6.6 \%$ (RB-2B) and $16.3 \%$ (RB-2A). The RB-3 pegmatite contained kaolinite only in the sample RB$3 \mathrm{~B}$ with $1.7 \%$, while the RB-4 pegmatite had the greatest content, 34.9\%. In the samples of RB-5 pegmatite, kaolinite contents between $17.2 \%$ (RB-5B) and $18.5 \%$ (RB-5A) were detected, while in RB-6 pegmatite, the kaolinite content was $23.9 \%$. The RB-7 pegmatite contained the $2^{\text {nd }}$ greatest kaolinite content, $33.3 \%$. Last, the SG-1C pegmatite had a kaolinite content of $10.1 \%$. Based on the regolith stratigraphy (RE) index, the samples CA-3, CA-4, RB-1, RB-2B, RB-

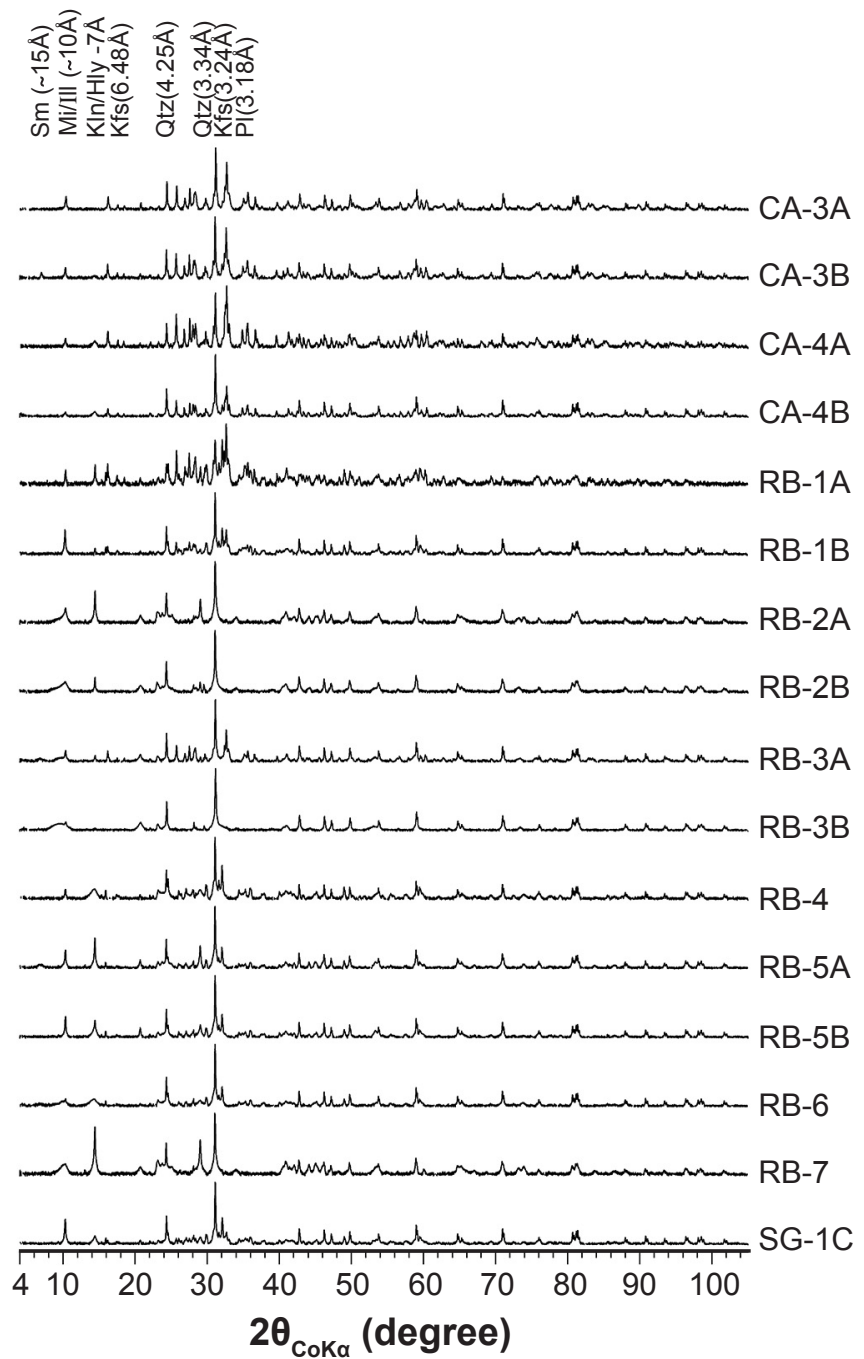

Figure 3: Normalized X-ray diffractograms of the bulk fractions separated by location ( $y$-axis in quadratic scale). Sm: smectite; Mi: mica; Ill: illite; Kln: kaolinite; Hly: halloysite; Qtz: quartz; Kfs: K-feldspar; Pl: plagioclase.

[Figura 3: Difratogramas de raios $X$ das frações brutas separados por localidade (eixo y em escala quadrática). Sm: esmectita; Mi. mica; Ill: illita; Kln: caulinita; Hly: halloysita; Qtz: quartzo; Kfs: K-feldspato; Pl: plagioclásio.]

3, and SG-1C came from the saprock zone, while samples RB-2A, RB-4, RB-5, RB-6, and RB-7 originated in the saprolite zone, which was where the greatest kaolinite and/or halloysite contents were found, between $16.3 \%$ and $34.9 \%$. Through the correlation between the results of chemical analysis obtained from quantitative mineral analysis and $\mathrm{XRF}$, it was possible to evaluate the refinement quality (Fig. 4). The Pearson correlation coefficient values ranged from 0.993 (RB-5A) to 1.000 (RB-1B), and the coefficient of determination $\left(\mathrm{R}^{2}\right)$ values ranged from $0.985(\mathrm{RB}-5 \mathrm{~A})$ to 0.999 (RB-1B).

Clay mineral assemblages: the mixture between kaolinite and/or halloysite and other clay minerals decreases the ore quality because beneficiation plants are unable to separate them. Therefore, clay mineral assemblages were determined 
Table IV - Results of quantitative mineral analysis of the bulk fractions obtained by the Rietveld method and its figures of merit and chemical analysis by XRF in oxides and calculated indexes.

[Tabela IV - Resultados de análise mineral quantitativa das frações brutas através do método de Rietveld e suas figuras de mérito, e análise química por FRX em óxidos e índices calculados.]

\begin{tabular}{|c|c|c|c|c|c|c|c|c|c|c|c|c|c|c|c|c|}
\hline & CA-3A & CA-3B & CA- $4 \mathrm{~A}$ & CA-4B & RB-1A & RB-1B & $\mathrm{RB}-2 \mathrm{~A}$ & RB-2B & $\mathrm{RB}-3 \mathrm{~A}$ & RB-3B & RB-4 & RB-5A & RB-5B & RB-6 & RB-7 & SG-1C \\
\hline \multicolumn{17}{|c|}{ Mineralogy (wt $\%)$} \\
\hline $\mathrm{Sm}$ & 0.0 & 0.1 & 0.0 & 0.0 & 0.0 & 0.0 & 0.0 & 0.0 & 0.0 & 3.1 & 0.0 & 7.2 & 0.0 & 0.0 & 0.0 & 0.0 \\
\hline $\mathrm{Mi}+\mathrm{Ill}$ & 4.5 & 3.1 & 1.0 & 4.5 & 3.9 & 13.0 & 45.3 & 46.2 & 8.5 & 46.9 & 1.5 & 7.7 & 9.5 & 22.9 & 41.4 & 16.0 \\
\hline $\mathrm{Kln}+\mathrm{Hly}$ & 0.0 & 0.0 & 4.0 & 4.5 & 6.4 & 1.6 & 16.3 & 6.6 & 1.7 & 0.0 & 34.9 & 18.5 & 17.2 & 23.9 & 33.3 & 10.1 \\
\hline Qtz & 31.9 & 27.8 & 13.6 & 44.8 & 9.2 & 35.5 & 38.4 & 47.2 & 31.8 & 50.0 & 27.1 & 44.3 & 48.5 & 36.4 & 25.4 & 43.3 \\
\hline Kfs & 2.6 & 7.1 & 1.2 & 6.0 & 20.8 & 23.9 & 0.0 & 0.0 & 2.8 & 0.0 & 36.6 & 22.3 & 24.8 & 16.8 & 0.0 & 24.7 \\
\hline $\mathrm{Pl}$ & 60.9 & 61.9 & 80.2 & 40.0 & 59.7 & 26.0 & 0.0 & 0.0 & 55.3 & 0.0 & 0.0 & 0.0 & 0.0 & 0.0 & 0.0 & 5.8 \\
\hline Sum & 99.9 & 100.0 & 100.0 & 99.8 & 100.0 & 100.0 & 100.0 & 100.0 & 100.1 & 100.0 & 100.1 & 100.0 & 100.0 & 100.0 & 100.1 & 99.9 \\
\hline \multicolumn{17}{|c|}{ Rietveld (wt $\%$ ) } \\
\hline $\mathrm{SiO}_{2}$ & 76.7 & 75.6 & 70.6 & 79.8 & 67.4 & 75.1 & 66.1 & 71.1 & 75.4 & 72.7 & 66.5 & 73.4 & 76.3 & 68.0 & 58.6 & 74.9 \\
\hline $\mathrm{Al}_{2} \mathrm{O}_{3}$ & 14.6 & 15.1 & 18.6 & 12.9 & 20.2 & 15.4 & 24.4 & 20.6 & 15.7 & 18.6 & 22.2 & 16.3 & 15.6 & 22.1 & 30.2 & 16.2 \\
\hline $\mathrm{CaO}$ & 0.7 & 0.7 & 0.9 & 0.4 & 0.7 & 0.3 & 0.0 & 0.0 & 0.6 & 0.0 & 0.0 & 0.1 & 0.0 & 0.0 & 0.0 & 0.1 \\
\hline $\mathrm{Na}_{2} \mathrm{O}$ & 6.8 & 6.9 & 9.0 & 4.5 & 6.7 & 2.9 & 0.0 & 0.0 & 6.2 & 0.0 & 0.0 & 0.1 & 0.0 & 0.0 & 0.0 & 0.7 \\
\hline $\mathrm{K}_{2} \mathrm{O}$ & 1.0 & 1.6 & 0.3 & 1.6 & 4.0 & 5.6 & 5.4 & 5.5 & 1.5 & 5.6 & 6.4 & 4.7 & 5.3 & 5.6 & 4.9 & 6.1 \\
\hline LOI & 0.2 & 0.2 & 0.6 & 0.8 & 1.1 & 0.8 & 4.1 & 2.8 & 0.6 & 3.0 & 4.9 & 5.5 & 2.8 & 4.3 & 6.3 & 2.1 \\
\hline Sum & 99.99 & 100.0 & 100.0 & 100.0 & 100.0 & 100.0 & 100.0 & 100.0 & 100.0 & 100.0 & 100.0 & 100.0 & 100.0 & 100.0 & 100.0 & 100.0 \\
\hline \multicolumn{17}{|c|}{ Chemistry (wt \%) } \\
\hline $\mathrm{SiO}_{2}$ & 70.80 & 69.70 & 63.80 & 75.10 & 64.50 & 73.60 & 60.40 & 70.80 & 72.30 & 71.20 & 63.00 & 67.40 & 70.90 & 67.70 & 57.00 & 71.50 \\
\hline $\mathrm{Al}_{2} \mathrm{O}_{3}$ & 18.20 & 18.70 & 24.10 & 16.60 & 22.20 & 15.60 & 26.40 & 16.00 & 17.30 & 18.10 & 25.90 & 23.30 & 20.50 & 21.90 & 30.10 & 19.40 \\
\hline $\mathrm{Fe}_{2} \mathrm{O}_{3}$ & 0.47 & 0.60 & 0.27 & 0.26 & 0.74 & 1.00 & 2.60 & 3.30 & 0.46 & 1.60 & 0.48 & 0.68 & 0.80 & 1.00 & 1.10 & 0.91 \\
\hline $\mathrm{MnO}$ & 0.00 & 0.00 & 0.00 & 0.00 & 0.00 & 0.00 & 0.15 & 0.05 & 0.00 & 0.00 & 0.00 & 0.00 & 0.00 & 0.00 & 0.00 & 0.00 \\
\hline $\mathrm{MgO}$ & 0.17 & 0.15 & 0.00 & 0.00 & 0.27 & 0.50 & 0.46 & 0.81 & 0.56 & 0.83 & 0.28 & 0.40 & 0.17 & 0.58 & 0.53 & 0.24 \\
\hline $\mathrm{CaO}$ & 1.40 & 1.50 & 2.50 & 1.40 & 0.15 & 0.51 & 0.00 & 0.00 & 0.27 & 0.05 & 0.00 & 0.00 & 0.00 & 0.00 & 0.00 & 0.20 \\
\hline $\mathrm{Na}_{2} \mathrm{O}$ & 7.10 & 7.30 & 7.40 & 4.20 & 6.20 & 3.20 & 0.00 & 0.00 & 4.50 & 0.19 & 0.31 & 0.17 & 0.22 & 0.23 & 0.00 & 1.10 \\
\hline $\mathrm{K}_{2} \mathrm{O}$ & 1.00 & 1.20 & 0.51 & 1.10 & 3.40 & 4.10 & 2.20 & 2.30 & 1.40 & 2.60 & 4.70 & 2.60 & 4.00 & 2.70 & 2.00 & 3.50 \\
\hline $\mathrm{TiO}_{2}$ & 0.00 & 0.00 & 0.00 & 0.00 & 0.05 & 0.15 & 0.15 & 0.83 & 0.05 & 0.51 & 0.00 & 0.19 & 0.05 & 0.10 & 0.43 & 0.00 \\
\hline $\mathrm{P}_{2} \mathrm{O}_{5}$ & 0.00 & 0.00 & 0.00 & 0.00 & 0.11 & 0.05 & 0.11 & 0.05 & 0.00 & 0.00 & 0.00 & 0.00 & 0.00 & 0.00 & 0.00 & 0.00 \\
\hline $\mathrm{ZrO}_{2}$ & 0.00 & 0.00 & 0.00 & 0.00 & 0.00 & 0.00 & 0.13 & 0.05 & 0.00 & 0.00 & 0.00 & 0.00 & 0.00 & 0.00 & 0.17 & 0.00 \\
\hline LOI & 0.65 & 0.74 & 1.20 & 1.20 & 2.40 & 1.20 & 7.20 & 6.00 & 3.20 & 5.10 & 5.40 & 5.20 & 3.40 & 5.70 & 8.80 & 2.80 \\
\hline Sum & 99.79 & 99.89 & 99.78 & 99.86 & 100.02 & 99.91 & 99.80 & 100.19 & 100.04 & 100.18 & 100.07 & 99.94 & 100.04 & 99.91 & 100.13 & 99.65 \\
\hline \multicolumn{17}{|c|}{ Index } \\
\hline CIA & 54.32 & 53.84 & 58.25 & 60.93 & 61.07 & 59.48 & 91.73 & 86.54 & 64.77 & 84.91 & 82.23 & 88.28 & 81.38 & 86.90 & 93.29 & 76.49 \\
\hline $\mathrm{RE}$ & 0.0 & 0.1 & 4.6 & 8.2 & 7.0 & 2.5 & 26.5 & 12.5 & 2.5 & 6.2 & 47.8 & 46.1 & 33.4 & 37.6 & 44.6 & 17.8 \\
\hline \multicolumn{17}{|c|}{ Parameter } \\
\hline$\varrho$ & 0.998 & 0.998 & 0.994 & 0.998 & 0.999 & 1.000 & 0.995 & 0.995 & 0.999 & 0.999 & 0.997 & 0.993 & 0.997 & 0.999 & 0.998 & 0.998 \\
\hline $\mathrm{R}^{2}$ & 0.995 & 0.995 & 0.988 & 0.996 & 0.998 & 0.999 & 0.990 & 0.990 & 0.997 & 0.997 & 0.994 & 0.985 & 0.993 & 0.998 & 0.996 & 0.996 \\
\hline \multicolumn{17}{|c|}{ Figure of merit* } \\
\hline GOF & 2.32 & 2.44 & 2.23 & 1.96 & 2.06 & 2.20 & 2.63 & 2.62 & 2.31 & 2.95 & 2.44 & 3.07 & 2.33 & 2.13 & 3.82 & 2.85 \\
\hline $\operatorname{Rexp}$ & 4.55 & 4.32 & 4.83 & 4.78 & 4.59 & 4.47 & 3.68 & 3.56 & 4.44 & 4.13 & 4.73 & 4.31 & 4.41 & 4.22 & 4.02 & 4.41 \\
\hline Rwp & 10.57 & 10.55 & 10.75 & 9.36 & 9.44 & 9.82 & 9.67 & 9.34 & 10.27 & 12.19 & 11.56 & 13.24 & 10.25 & 9.01 & 15.36 & 12.54 \\
\hline
\end{tabular}

Sm: smectite; Mi+Ill: mica+illite; Ill: illite; Kln+Hly: kaolinite+halloysite; Qtz: quartz; Kfs: K-feldspar; Pl: plagioclase; LOI: loss on ignition; CIA: chemical index of alteration; RE: regolith stratigraphy; Q: Pearson correlation coefficient; $R^{2}$ : coefficient of determination; * evaluates the quality of the Rietveld refinement (the lower the value, the better the refinement); GOF: goodness of fit; Rexp: expected R-value; Rwp: weighted-profile R-value.

(Fig. 5). Despite the identification of smectite in the clay size fraction diffractograms, the small contents of the mineral caused difficulties in bulk fractions' quantification, since smectite's main reflections in XRD, close to $15 \AA(001)$, are only well-identified when reasonable quantities of the mineral are present. Smectite was identified in samples CA- 


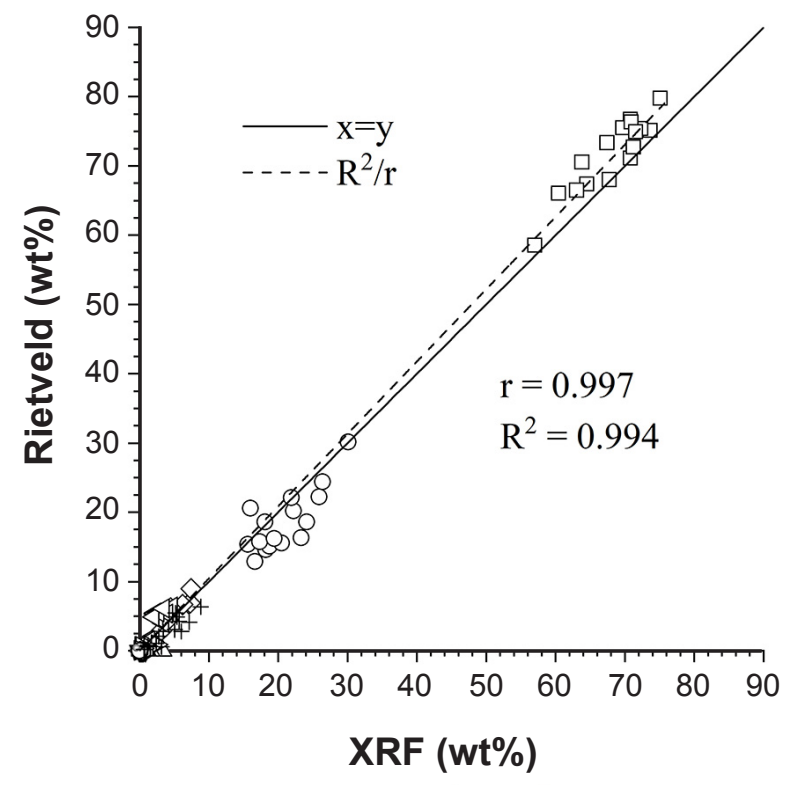

$\begin{array}{llllllll}\square & \mathrm{SiO}_{2} & \nabla & \mathrm{MgO} & \triangleright & \mathrm{CaO} & \diamond & \mathrm{ZrO}_{2} \\ \diamond & \mathrm{Al}_{2} \mathrm{O}_{3} & \diamond & \mathrm{Na}_{2} \mathrm{O} & \diamond & \mathrm{TiO}_{2} & \diamond & \mathrm{P}_{2} \mathrm{O}_{5} \\ \triangle & \mathrm{Fe}_{2} \mathrm{O}_{3} & \triangleleft & \mathrm{K}_{2} \mathrm{O} & \star & \mathrm{MnO} & + & \mathrm{LOI}\end{array}$

Figure 4: Correlation between the chemical compositions obtained from the conversion of the quantitative mineral analysis and X-ray fluorescence spectroscopy to evaluate the Rietveld refinement quality. The Pearson correlation coefficient and the $\mathrm{R}^{2}$ value shown are related to all data.

[Figura 4: Correlação entre as composições químicas obtidas pela conversão da análise mineral quantitativa e espectroscopia de fluorescência de raios $X$ visando avaliar a qualidade dos refinamentos por Rietveld. $O$ coeficiente de correlação de Pearson e o valor de $R^{2}$ apresentados estão relacionados a todos os dados.]

3, RB-1, RB-3, RB-5, RB-6, and SG-1C by reflections at 15 $\AA$, which expanded to $17 \AA$ after treatment with ethyleneglycol and collapsed after heating at $550{ }^{\circ} \mathrm{C}$. Illite was identified in all the samples by reflections at $10 \AA$, which did not change after ethylene glycol treatment and heating at 550 ${ }^{\circ} \mathrm{C}$. Kaolinite was identified in all the samples by reflections at $7 \AA$, which did not undergo changes after ethylene glycol treatment and collapsed after heating at $550{ }^{\circ} \mathrm{C}$. Rectorite, an interstratified clay mineral between mica and smectite [40], was found in samples RB-2A and RB-3B by reflection at 24 $\AA$, which expanded to $26.5 \AA$ after ethylene glycol treatment. Through d(060) reflections, it was possible to identify clay mineral species. Montmorillonite was determined as the smectite group clay mineral because of reflections at 1.50 $\AA$, which is also associated with illite, while kaolinite and/ or halloysite were identified by reflections at $1.49 \AA$ [37].

In the quantitative analysis of the clay mineral phases (Table V), the samples CA-3A and CA-3B were found to be mostly composed of montmorillonite, with concentrations of $67 \%$ and $47 \%$, followed by kaolinite with values of $10 \%$ and $31 \%$ and illite with values of $24 \%$ and $22 \%$, respectively. The samples CA-4A and CA-4B were almost entirely composed of kaolinite, with contents of $77 \%$ and

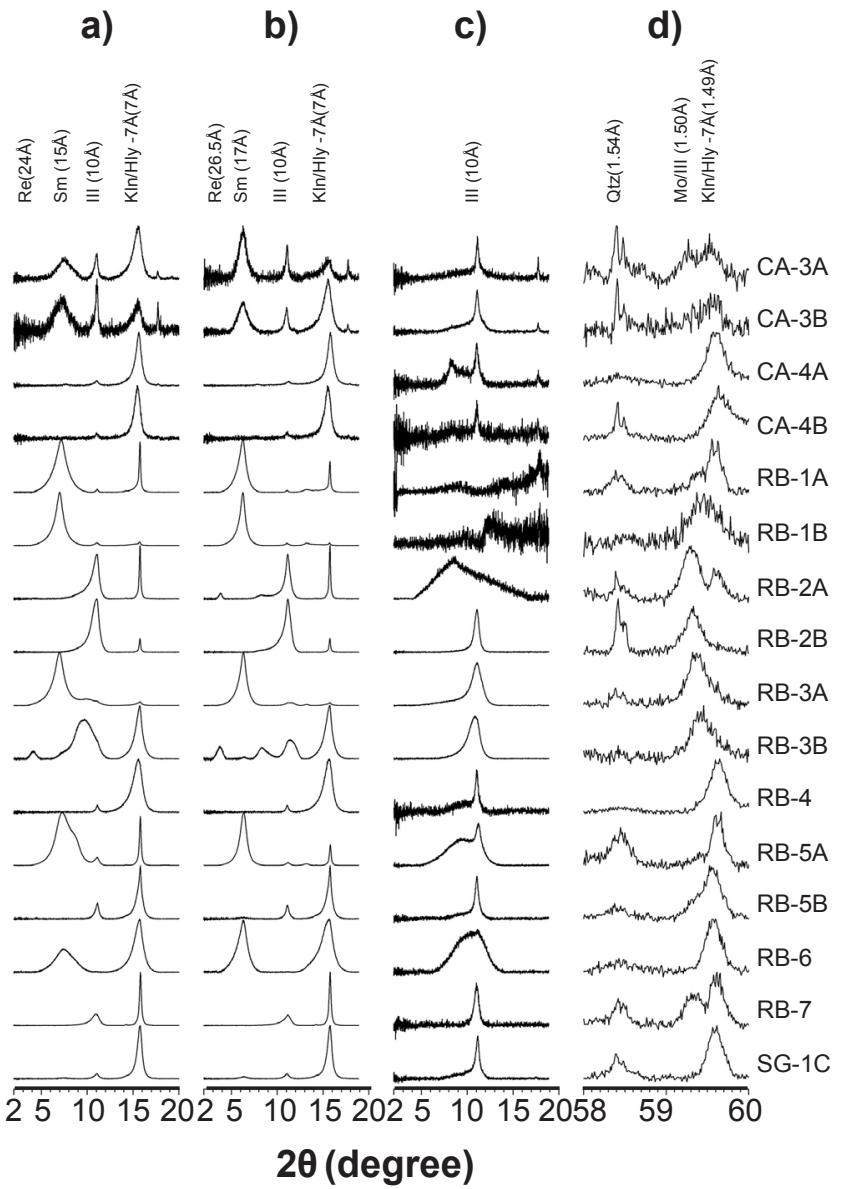

Figure 5: Normalized X-ray diffractograms of the clay size fractions prepared by air drying (a), solvated with ethylene glycol (b), and heated at $550{ }^{\circ} \mathrm{C}$ (c) on oriented slides and with random mounted fractions in the region between 1.84 and $1.46 \AA$ for the investigations of $\mathrm{d}(060)$ reflections (d) to determine the species of clay minerals. Re: rectorite; Sm: smectite; Mo: montmorillonite; Ill: illite; Kln: kaolinite; Hly: halloysite; Qtz: quartz. Radiation: $\operatorname{CoK} \alpha(\mathrm{a}, \mathrm{b}, \mathrm{c}) ; \mathrm{CuK} \alpha(\mathrm{d})$.

[Figura 5: Difratogramas de raios $X$ normalizados das frações de argila preparadas como lâminas orientadas secas ao ar (a), solvatadas com etilenoglicol (b) e aquecidas a $550{ }^{\circ} \mathrm{C}(\mathrm{c}) \mathrm{e}$ com montagem randômica na região entre 1,84 e 1,46 A para investigação das reflexões de d(060) (d) para determinação dos argilominerais. Re: rectorita; Sm: esmectita; Mo: montmorillonita; Ill: illita; Kln: caulinita; Hly: halloysita, Qtz: quartzo. quartzo. Radiação: $\operatorname{CoK\alpha }(a, b, c) ; C u K \alpha(d)$.]

$82 \%$, and illite had values of $23 \%$ and $17 \%$, respectively. Samples RB-1A and RB-1B were found to be composed of montmorillonite with contents of $91 \%$ and $94 \%$, kaolinite with values of $7 \%$ and $3 \%$, and illite with values of $1 \%$ and 3\%, respectively. Samples RB-2A and RB-2B were composed mostly of illite, with concentrations of $86 \%$ and $99 \%$, and in lesser proportions by kaolinite, with values of $6 \%$ and $1 \%$, respectively. In sample RB-2A, rectorite was observed, with a content of $7 \%$. Sample RB-3A was composed of $93 \%$ montmorillonite, $6 \%$ illite, and $1 \%$ kaolinite, while sample RB-3B presented 60\% illite, $20 \%$ rectorite, $19 \%$ kaolinite, and $1 \%$ montmorillonite. Sample 
Table V - Results of quantitative mineral analysis (wt\%) of the clay minerals based on the X-ray diffractograms of ethylene glycol-solvated, oriented slides (Biscaye's method) [38].

[Tabela $V$ - Resultados de análise mineral quantitativa (\% em massa) dos argilominerais com base nos difratogramas de raios $X$ das lâminas orientadas tratadas com etilenoglicol (método de Biscaye) [38].]

\begin{tabular}{ccccc}
\hline Sample & Re & Mo & Ill & Kln/Hly \\
\hline CA-3A & 0 & 67 & 24 & 10 \\
CA-3B & 0 & 47 & 22 & 31 \\
CA-4A & 0 & 0 & 23 & 77 \\
CA-4B & 0 & 0 & 17 & 82 \\
RB-1A & 0 & 91 & 1 & 7 \\
RB-1B & 0 & 94 & 3 & 3 \\
RB-2A & 7 & 0 & 86 & 6 \\
RB-2B & 0 & 0 & 99 & 1 \\
RB-3A & 0 & 93 & 6 & 1 \\
RB-3B & 20 & 1 & 60 & 19 \\
RB-4 & 0 & 0 & 12 & 88 \\
RB-5A & 0 & 93 & 3 & 3 \\
RB-5B & 0 & 1 & 40 & 59 \\
RB-6 & 0 & 69 & 0 & 31 \\
RB-7 & 0 & 0 & 74 & 26 \\
SG-1C & 0 & 8 & 22 & 70 \\
\hline
\end{tabular}

Re: rectorite; Mo: montmorillonite; Ill: illite; Kln/Hly: kaolinite and/or halloysite.

RB-4 contained the highest concentration of kaolinite mixed with halloysite (88\%), with $12 \%$ illite as an impurity. Sample RB-5A presented 93\% montmorillonite, $3 \%$ illite, and 3\% kaolinite and/or halloysite, while sample RB-5B showed 59\% kaolinite, $40 \%$ illite, and 1\% montmorillonite. Sample RB-6 contained 69\% montmorillonite and 31\% kaolinite, while sample RB-7 contained $74 \%$ illite and $26 \%$ kaolinite. Last, sample SG-1C contained $70 \%$ kaolinite, $22 \%$ illite, and $8 \%$ montmorillonite.

Scanning electron microscopy (SEM): SEM was used mainly to distinguish kaolinite from halloysite because it is difficult to differentiate clay minerals that have plate morphology. In sample CA-3B, the montmorillonite crystals were placoid, irregular, and had dimensions from 2 to $3 \mu \mathrm{m}$ (Fig. 6A). In sample CA-4A, kaolinite and illite crystals presented plate geometry with diameters less than $2 \mu \mathrm{m}$ (Fig. 6B). In sample RB-1A, montmorillonite crystals had plate geometry and size greater than $2 \mu \mathrm{m}$, reaching $6 \mu \mathrm{m}$ (Fig. 6C). In sample RB-2A, illite crystals were well individualized, had plate geometry with diameters close to $2 \mu \mathrm{m}$ (Fig. 6D). In sample RB-3A, montmorillonite presented spider-web texture, and illite and kaolinite had plate geometry (Fig. 6E). In sample RB-4, kaolinite and tubular halloysite crystals were mixed and showed a length of $5 \mu \mathrm{m}$, in which illite also occurred (Figs. 6F and 6G). Sample RB-5A contained a mixture of kaolinite and tubular halloysite with a length of at most $4 \mu \mathrm{m}$, though montmorillonite represented most of the clay fraction (Fig. 6H). Sample RB-6 contained montmorillonite and kaolinite (Figs. 6I and 6J), while sample RB-7 contained kaolinite and illite with plate geometry and diameters close to $1.5 \mu \mathrm{m}$ (Fig. 6K). Last, sample SG-1C contained kaolinite, illite, and montmorillonite with plate geometry (Fig. 6L).

\section{DISCUSSION}

Regolith stratigraphy and genesis: through chemical analysis, it was also possible to calculate the chemical index of alteration (CIA) [39], which indicated the weathering degree to which the samples were submitted. In this regard, a Pearson correlation matrix was constructed with the CIA values, quantitative mineral analysis, and chemical analysis by XRF (Table VI). The strong positive correlation between CIA and kaolinite and/or halloysite contents (0.70) indicated that the greater the weathering degree was, the higher the mineral content was, which established that the mineral occurrences had a weathered origin. Furthermore, the very strong negative correlation between plagioclase and CIA (-0.91) as well as CIA and $\mathrm{Na}_{2} \mathrm{O}(-0.94)$, the strong negative correlation between CIA and $\mathrm{CaO}(-0.76)$, and moderate correlation, almost strong, between kaolinite and/ or halloysite and plagioclase contents $(-0.63)$ indicated that when crystals of plagioclase weather, they turn into kaolinite and/or halloysite. In contrast with these associations, $\mathrm{K}$-feldspar and mica presented positive correlations with kaolinite and/or halloysite, ruling them out as precursors. The moderate negative correlation between feldspar and kaolinite and/or halloysite (-0.49), less than that observed for plagioclase and kaolinite and/or halloysite (-0.63), indicated that K-feldspar did not form kaolinite and/or halloysite and that only plagioclase participates in the reaction, through [41]:

$$
\begin{gathered}
\left(\mathrm{Ca}, \mathrm{Na}_{2}\right) \mathrm{Al}_{2} \mathrm{Si}_{2} \mathrm{O}_{8}+2 \mathrm{H}^{+}+\mathrm{H}_{2} \mathrm{O} \rightarrow \underset{2}{\text { (plagioclase) }} \mathrm{Al}_{2} \mathrm{Si}_{2} \mathrm{O}_{5}(\mathrm{OH})_{2}+\mathrm{Na}^{+}+\mathrm{Ca}^{2+} \\
\text { (kaolinite/halloysite) }
\end{gathered}
$$

Comparisons with other kaolin deposits: the samples with the highest kaolinite and/or halloysite quantities were compared to the sedimentary deposits of the Northern Brazilian region [28] and to the Campo Alegre deposit in Santa Catarina [27], which is a deposit originated from the weathering of volcanic acid rocks (Table VII). The selected samples in the CampoAlegre deposit used to compare with the kaolin deposits from Rio de Janeiro were made considering the similarity of geological settings. It is quite difficult to find reliable and complete data regarding quantitative mineral analysis in bulk samples from kaolin deposits, which explain this limited comparison. In comparison to the sedimentary deposits from the Northern region, the kaolin occurrences from Rio de Janeiro presented lower kaolinite and/or halloysite contents, which was already expected 

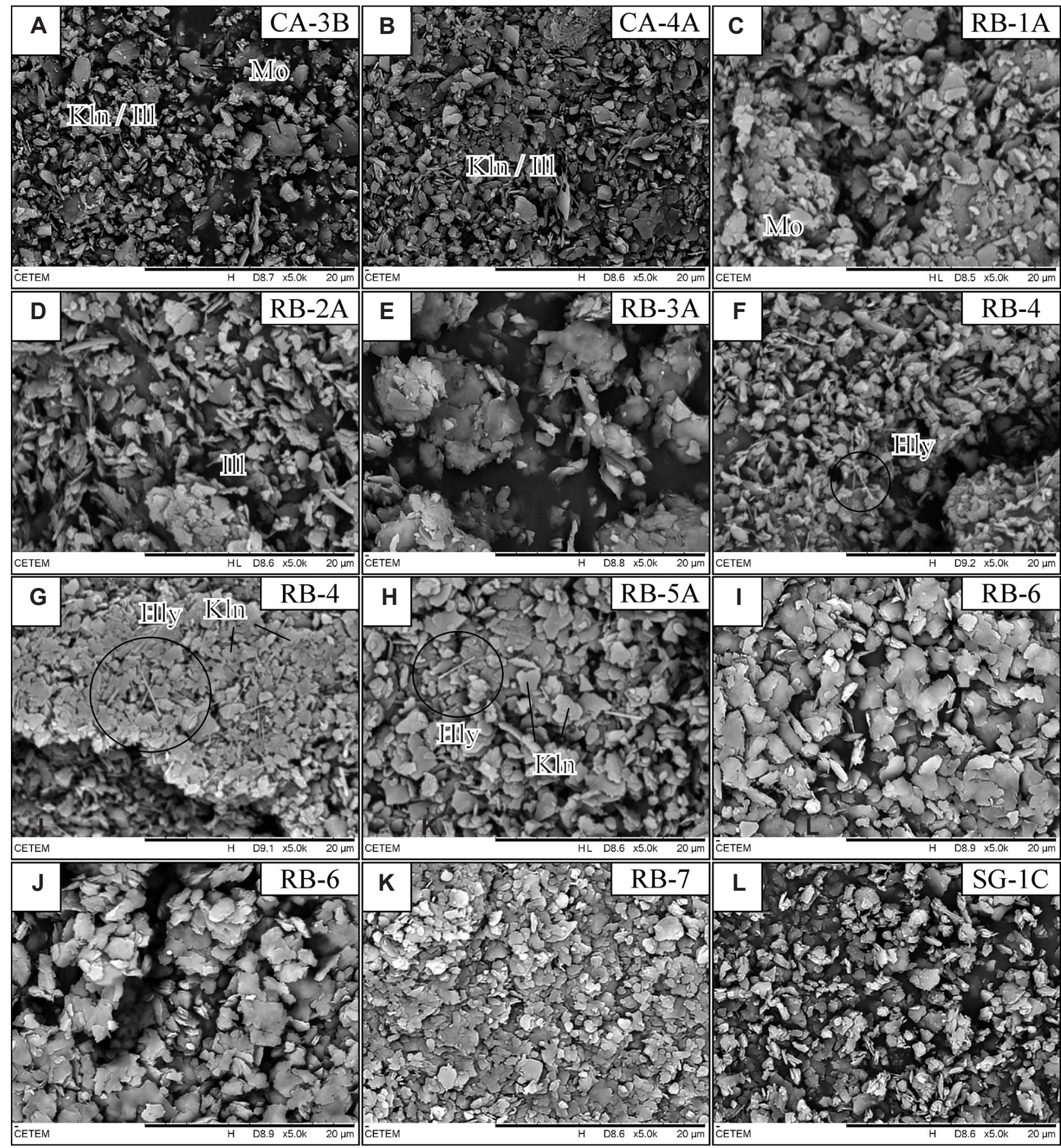

Figure 6: SEM images of clay size fractions: A) montmorillonite, illite, and kaolinite in fraction CA-3B; B) kaolinite and illite in fraction CA-4A; C) montmorillonite in fraction RB-1A; D) illite in fraction RB-2A; E) montmorillonite in fraction RB-3A; F,G) kaolinite and tubular halloysite in fraction RB-4; H) kaolinite and tubular halloysite in fraction RB-5A; I,J) kaolinite and montmorillonite in fraction RB$6 ; \mathrm{K})$ kaolinite and illite in fraction RB-7; and L) kaolinite and illite in fraction SG-1C.

[Figura 6: Imagens de microscopia eletrônica de varredura das frações de argila: A) montmorillonita, illita e caulinita na fração CA-3B; $B)$ caulinita e illita na fração $C A-4 A ; C)$ montmorillonita na fração $R B-1 A ; D$ ) illita na fração $R B-2 A ; E$ ) montmorillonita na fração RB-3A; $F, G)$ caulinita e halloysita tubular na fração RB-4; H) caulinita e halloysita tubular na fração RB-5A; I,J) caulinita e montmorillonita na fração RB-6; K) caulinita e illita na fração RB-7; e L) caulinita e illita na fração $S G-1 C$.]

because sedimentary deposits tend to be almost completely composed of kaolinite and/or halloysite. Concerning to the Campo Alegre deposits, which are more similar to the kaolin occurrences from Rio de Janeiro, the contents of kaolinite and/or halloysite are close to values found in the Oxford mine (Ox1), indicating that the contents of kaolinite and/ 
Table VI - Pearson correlation matrix between the chemical index of alteration (CIA) and the results of quantitative mineral and chemical analyses.

[Tabela VI - Matriz de correlação de Pearson entre o índice químico de alteração (CIA) e resultados de análises mineral quantitativa e química.]

\begin{tabular}{|c|c|c|c|c|c|c|c|c|c|c|c|c|c|c|c|c|c|c|c|c|}
\hline & CIA & $\mathrm{Sm}$ & $\begin{array}{c}\mathrm{Mi}+ \\
\text { Ill } \\
\end{array}$ & $\begin{array}{c}\text { Kln+ } \\
\text { Hly }\end{array}$ & Qtz & Kfs & $\mathrm{Pl}$ & Fs & $\mathrm{SiO}_{2}$ & $\mathrm{Al}_{2} \mathrm{O}_{3}$ & $\mathrm{Fe}_{2} \mathrm{O}_{3}$ & $\mathrm{MnO}$ & $\mathrm{MgO}$ & $\mathrm{CaO}$ & $\mathrm{Na}_{2} \mathrm{O}$ & $\mathrm{K}_{2} \mathrm{O}$ & $\mathrm{TiO}_{2}$ & $\mathrm{P}_{2} \mathrm{O}_{5}$ & $\mathrm{ZrO}_{2}$ & LOI \\
\hline \multicolumn{21}{|l|}{ CIA } \\
\hline $\mathrm{Sm}$ & 0.32 & & & & & & & & & & & & & & & & & & & \\
\hline $\mathrm{Mi}+\mathrm{Ill}$ & 0.70 & 0.04 & & & & & & & & & & & & & & & & & & \\
\hline Kln+Hly & 0.70 & 0.05 & 0.16 & & & & & & & & & & & & & & & & & \\
\hline Qtz & 0.45 & 0.34 & 0.42 & -0.05 & & & & & & & & & & & & & & & & \\
\hline Kfs & 0.05 & 0.11 & -0.49 & 0.40 & -0.01 & & & & & & & & & & & & & & & \\
\hline $\mathrm{Pl}$ & -0.91 & -0.29 & -0.62 & -0.63 & -0.65 & -0.28 & & & & & & & & & & & & & & \\
\hline Fs & -0.92 & -0.30 & -0.83 & -0.49 & -0.68 & 0.12 & 0.92 & & & & & & & & & & & & & \\
\hline $\mathrm{SiO}_{2}$ & -0.45 & 0.03 & -0.26 & -0.67 & 0.53 & 0.07 & 0.17 & 0.20 & & & & & & & & & & & & \\
\hline $\mathrm{Al}_{2} \mathrm{O}_{3}$ & 0.51 & 0.07 & 0.15 & 0.78 & -0.42 & 0.07 & -0.26 & -0.24 & -0.95 & & & & & & & & & & & \\
\hline $\mathrm{Fe}_{2} \mathrm{O}_{3}$ & 0.57 & -0.03 & 0.85 & 0.03 & 0.40 & -0.35 & -0.53 & -0.68 & -0.14 & -0.03 & & & & & & & & & & \\
\hline $\mathrm{MnO}$ & 0.39 & -0.12 & 0.56 & 0.08 & 0.17 & -0.34 & -0.28 & -0.42 & -0.35 & 0.24 & 0.72 & & & & & & & & & \\
\hline $\mathrm{MgO}$ & 0.59 & 0.22 & 0.78 & 0.09 & 0.37 & -0.23 & -0.56 & -0.67 & -0.03 & -0.09 & 0.69 & 0.24 & & & & & & & & \\
\hline $\mathrm{CaO}$ & -0.76 & -0.22 & -0.51 & -0.51 & -0.39 & -0.34 & 0.81 & 0.70 & 0.16 & -0.19 & -0.47 & -0.22 & -0.67 & & & & & & & \\
\hline $\mathrm{Na}_{2} \mathrm{O}$ & -0.94 & -0.29 & -0.64 & -0.64 & -0.62 & -0.23 & 0.98 & 0.93 & 0.20 & -0.29 & -0.53 & -0.30 & -0.59 & 0.82 & & & & & & \\
\hline $\mathrm{K}_{2} \mathrm{O}$ & 0.37 & 0.04 & 0.02 & 0.45 & 0.17 & 0.83 & -0.60 & -0.27 & -0.03 & 0.09 & 0.11 & -0.06 & 0.22 & -0.69 & -0.56 & & & & & \\
\hline $\mathrm{TiO}_{2}$ & 0.54 & 0.19 & 0.81 & 0.04 & 0.38 & -0.41 & -0.49 & -0.67 & -0.07 & -0.07 & 0.79 & 0.24 & 0.79 & -0.41 & -0.51 & 0.02 & & & & \\
\hline $\mathrm{P}_{2} \mathrm{O}_{5}$ & 0.05 & -0.19 & 0.28 & -0.10 & -0.25 & -0.04 & 0.00 & -0.01 & -0.28 & 0.10 & 0.52 & 0.66 & 0.18 & -0.26 & 0.00 & 0.21 & 0.15 & & & \\
\hline $\mathrm{ZrO}_{2}$ & 0.55 & -0.15 & 0.67 & 0.46 & -0.05 & -0.44 & -0.37 & -0.55 & -0.70 & 0.62 & 0.51 & 0.58 & 0.30 & -0.29 & -0.39 & -0.12 & 0.43 & 0.32 & & \\
\hline LOI & 0.94 & 0.20 & 0.74 & 0.73 & 0.22 & -0.10 & -0.77 & -0.84 & -0.62 & 0.62 & 0.57 & 0.43 & 0.64 & -0.72 & -0.82 & 0.24 & 0.58 & 0.14 & 0.72 & \\
\hline
\end{tabular}

Sm: smectite; Mi+Ill: mica+illite; Kln+Hly: kaolinite+halloysite; Qtz: quartz; Kfs: K-feldspar; Pl: plagioclase; LOI: loss on ignition.

Table VII - Comparison between the results of quantitative mineral analyses of the three most interesting kaolin occurrences from Rio de Janeiro, two giant sedimentary kaolin deposits at the North Brazilian region, and the Campo Alegre kaolin deposit in Santa Catarina, Brazil.

[Tabela VII - Comparação entre resultados de análises minerais quantitativas das três mais interessantes ocorrências de caulim do Rio de Janeiro, dois depósitos gigantes de caulim da região Norte do Brasil e depósito de Campo Alegre em Santa Catarina, Brasil.]

\begin{tabular}{ccccccccc}
\hline \multirow{2}{*}{ Mineralogy } & \multicolumn{2}{c}{$\begin{array}{c}\text { Sedimentary deposits [28] } \\
\text { Capim }\end{array}$} & \multicolumn{3}{c}{ Campo Alegre [27] } & \multicolumn{3}{c}{ This study } \\
& River & Jari River & Ox1 & Inc2a & Ce2m & RB-4 & RB-6 & RB-7 \\
\hline Mica+illite & 0.0 & 0.0 & 6.4 & 20.9 & 48.0 & 1.5 & 22.9 & 41.4 \\
Kaolinite+halloysite & 100.0 & 100.0 & 35.0 & 65.8 & 44.3 & 34.9 & 23.9 & 33.3 \\
Gibbsite & 0.0 & 0.0 & 1.5 & 0.0 & 0.0 & 0.0 & 0.0 & 0.0 \\
Quartz & 0.0 & 0.0 & 4.5 & 13.2 & 7.7 & 27.1 & 36.4 & 25.4 \\
K-feldspar & 0.0 & 0.0 & 52.5 & 0.0 & 0.0 & 36.6 & 16.8 & 0.0 \\
Sum & 100.0 & 100.0 & 99.9 & 99.9 & 100.0 & 100.1 & 100.0 & 100.1 \\
\hline
\end{tabular}

or halloysite observed in the kaolin occurrences from Rio de Janeiro are close to those found in the market. However, reserve estimations should be made to evaluate the real economic importance of these deposits. Despite the economic contents of kaolinite and/or halloysite observed in some of the kaolin occurrences from Rio de Janeiro, information about the size and volume of deposits would provide fundamental data on the importance of these possible deposits.

\section{CONCLUSIONS}

The highest kaolinite and/or halloysite content was found 
in the RB-4 pegmatite body, which contained kaolinite mixed with tubular halloysite at a concentration of $34.9 \%$, in which kaolinite and halloysite represented values close to $88 \%$ in the clay mineral assemblages. The $2^{\text {nd }}$ greatest kaolinite content was found in the RB-7 pegmatite, with $33.3 \%$, representing only $26 \%$ of the clay mineral assemblage, with illite as its main component with $74 \%$. The $3^{\text {rd }}$ highest was found in the RB-6 pegmatite, in which kaolinite occurred alone with the content of $23.9 \%$, which accounted for $31 \%$ of the clay mineral assemblage. The other pegmatites presented kaolinite and/or halloysite contents ranging from 0 to $18.5 \%$. The samples located in the saprolite zone had the highest kaolinite and/or halloysite contents, following what was observed in the samples RB-2A, RB-4, RB-5, RB-6, and RB-7 (all from Niterói-Rio Bonito area, Brazil). Kaolinite and/or halloysite were generated by weathering processes, in which plagioclase was the most important mineral generator, while K-feldspar and mica were not present in the processes. The market involving industrial ores is more sensitive to economics than traditional ores such as iron and gold. This type of segment is extremely dependent on several economic factors such as current demand, distance from the processing industries, transportation, among others. The economic players must know the available deposits or occurrences of kaolin in Rio de Janeiro, which could lead to new prospects in the future. Furthermore, it is suggested to estimate the reserves of the studied bodies to better evaluate their importance.

\section{ACKNOWLEDGMENTS}

We would like to thank the Center for Mineral Technology (CETEM/MCTIC), Federal University of Rio de Janeiro (UFRJ/MEC), the National Council for Scientific and Technological Development (CNPq/MCTIC) for the scholarship (grant number: 131195/2019-0), Federal Rural University of Rio de Janeiro (UFRRJ/MEC), and the Rio de Janeiro State Research Support Foundation (FAPERJ/SCT$\mathrm{RJ})$.

\section{REFERENCES}

[1] H.H. Murray, in "Applied clay mineralogy", 1, Elsevier, Amsterdam (2007) 85.

[2] H.H. Murray, Int. J. Miner. Process. 7 (1980) 263.

[3] G.J. Churchman, P. Pasbakhsh, S. Hillier, Clay Miner. 51, 3 (2016) 303.

[4] P. Pasbakhsh, G.J. Churchman, J.L. Keeling, Appl. Clay Sci. 74, 1 (2013) 47.

[5] V. Vergaro, E. Abdullayev, Y.M. Lvov, A. Zeitoun, R. Cingolani, R. Rinaldi, S. Leporatti, Biomacromolecules 11, 3 (2010) 820.

[6] B. Guo, Q. Zou, Y. Lei, D. Jia, Polym. J. 41 (2009) 835.

[7] D.G. Shchukin, S.V. Lamaka, K.A. Yasakau, M.L. Zheludkevich, M.G.S. Ferreira, H. Möhwald, J. Phys. Chem. 112, 4 (2008) 958.

[8] M.S. Prasad, K.J. Reid, H.H. Murray, Appl. Clay Sci. 6
(1991) 87.

[9] R. Gill, Igneous rocks and processes: a practical guide, Wiley-Blackwell, Oxford (2010) 375.

[10] W.D. Johnston Jr, Geol. Soc. Am. Bull. 56, 11 (1945) 1015.

[11] K.M. Scoot, C.F. Pain (Eds.), "Regolith science", CSRI Publ., Oxford (2009) 106.

[12] H.G. Dill, R. Dohrmann, S. Kaufhold, S. Balaban, Ore Geol. Rev. 69 (2015) 33.

[13] J.M. Parker III, "Residual kaolin deposits of the Spruce Pine District, North Carolina", Techn. Report, North Carolina Dept. Conserv. Devel., USA (1946).

[14] G.E. Ekosse, Appl. Clay Sci. 50 (2010) 212.

[15] H.M. Fentaw, T. Mengistu, Appl. Clay Sci. 13 (1998) 149.

[16] M.A. Saddiqui, Z. Ahmed, J. Sci. Eng. 30 (2005) 195. [17] ANM, "Sumário mineral", DNPM/MME, Brazil (2019) 78.

[18] D.J. Sousa, A.F.D.C Varajão, J. Yvon, G.M. Da Costa, Clay Miner. 42 (2007) 69.

[19] C.R. Montes, A.J. Melfi, A. Carvalho, A.C. VieiraCoelho, M.L. Formoso, Clays Clay Miner. 50, 4 (2002) 494.

[20] V.M.J. Salgado Campos, L.C. Bertolino, L.C.S. Nascimento, J.Y.P. Leite, V.S. Brandão, O.C. Alves, J. Tolentino Jr., Clay Miner. 54, 3 (2019) 283.

[21] V.M.J.S. Campos, L.C. Bertolino, O.C. Alves, Cerâmica 63, 367 (2017) 369.

[22] E.P. Scorza, "Província pegmatítica da Borborema", Boletim 112, DNPM-DGM/MME, Rio Janeiro, Brazil (1944) 58.

[23] L.C. Bertolino, D.M.C. Rodrigues, C.L. Roland, O.C. Alves, E. Santos Filho, Anu. Inst. Geociên. UFRJ 35, 2 (2012) 65.

[24] Y.S. Visconti, N.B.F. Nicot, Cerâmica 2, 6 (1956) 59.

[25] I.R. Wilson, H. Souza Santos, P. Souza Santos, Cerâmica 44, 287-288 (1998) 118.

[26] P. Souza Santos, S. Perche Toledo, H. Souza Santos, Cerâm. Ind. 14, 1 (2009) 14.

[27] M.T.G. De Oliveira, S.M.A. Furtado, M.L.L. Formoso, R.A. Eggleton, N. Dani, An. Acad. Bras. Ciênc. 79, 4 (2007) 665.

[28] I.R. Wilson, H. Souza Santos, P. Souza Santos, Clay Miner. 41, 3 (2006) 697.

[29] Y.S. Visconti, N.B.F. Nicot, Cerâmica 3, 10 (1957) 72. [30] P. Souza Santos, H. Souza Santos, A.C. Moniz, Cerâmica 8 (1962) 2.

[31] P. Souza Santos, A.C. Pimentel, Cerâmica 17, 67 (1971) 258.

[32] S.O. Menezes, "Principais pegmatitos do estado do Rio de Janeiro: principais depósitos minerais do Brasil", v.4b, DNPM/CPRM, Brasília (1997) 405.

[33] S.O. Menezes, "Catálogo dos principais pegmatitos do estado do Rio de Janeiro", Niterói, DRM-RJ (1982).

[34] M. Heilbron, L.G. Eirado, J. Almeida, "Mapa geológico e de recursos minerais do estado do Rio de Janeiro", CPRM, Belo Horizonte (2016).

[35] Int. Centre Diffract. Data, PDF4+ (ICDD), Newton 
Square (2012).

[36] G.W. Brindley, G. Brown, "Crystal structures of clay minerals and their X-ray identification", Miner. Soc. Monogr. 5, London (1980) 411.

[37] D.M. Moore, R.C. Reynolds, X-ray diffraction and the identification and analysis of clay minerals, $2^{\text {nd }}$ ed., Oxford Un. Press, Oxford (1997).

[38] P.E. Biscaye, Geol. Soc. Am. Bull. 76, 7 (1965) 803.

[39] H.W. Nesbitt, G.M. Young, Nature 299, 5885 (1982)
715.

[40] H.C. Starkey, P.D. Blackmon, P.L. Hauff, "The routine mineralogical analysis of clay-bearing samples", U.S. Geol. Survey Bull. 1563, US Gov. Print. Office, Washington (1984) plate 1.

[41] L. Robb, Introduction to ore-forming processes, Blackwell Publ., Oxford (2005).

(Rec. 20/03/2020, Rev. 26/05/2020, 22/06/2020, Ac. 29/06/2020) 